\title{
Světlana: Partisans and Power in Post-War Czechoslovakia
}

\author{
Mira Markham (1) \\ Department of History, University of North Carolina at Chapel Hill, 554A Pauli Murray Hall, 102 Emerson Drive, Chapel \\ Hill, NC 27514, USA \\ miram@live.unc.edu
}

\begin{abstract}
After the renewal of national independence in 1945 former anti-fascist partisans were among the Czechoslovak Communist Party's most reliable and radical allies. Nevertheless, following the communist coup of 1948, a group of partisans in the rural region of Moravian Wallachia began to mobilise wartime networks and tactics against the consolidating party dictatorship, establishing the Světlana resistance network. Simultaneously, state authorities also drew on partisan practices to reconstitute opposition and resistance in this region as evidence of an international conspiracy that could be understood and prosecuted within the framework of official ideology and propaganda. This article analyses the case of Světlana to examine the politics of people's democracy in Czechoslovakia and explore local dynamics of resistance and repression during the early years of the communist regime.
\end{abstract}

On a Sunday night in April 1949 the local branch of the Czechoslovak Communist Party in the village of Pozděchov sponsored a dance in a local tavern. After the musicians had been paid and the merrymakers were returning home, a group of armed men appeared before the tavern's doors and forced the village party chairman against the wall. One searched the chairman's pockets, found his official document stamp and threw it to the ground. Another pressed a pistol to the chairman's chest and tore the party insignia from his jacket. 'You communists want to destroy what we fought for', the armed man reportedly said. 'You won't be wearing this anymore. We'll let you live for today, but do as we say.' As the chairman fled he heard gunshots. A struggle had broken out, and one of the men fired wildly, hitting a bystander in the leg. When a car suddenly drove past the tavern, the armed men disappeared into the forest. ${ }^{1}$

Police officers arrived in Pozděchov the next morning. Villagers could not - or, the officers suspected, would not - reveal the names of all the attackers. But they did identify them as former partisans, members of the armed resistance to Nazi occupation that had been active in the area during the final months of the Second World War. ${ }^{2}$ The identities of the armed men were not revealed publicly until the following year, when Alois Šimara, Ludvík Šmotek and Antonín Kratina, along with thirty

1 Protokol sepsaný s Josefem Bolelouckým; Protokol sepsaný s Františkem Hanačíkem; Protokol sepsaný s Jaroslavem Kratinou; Protokol sepsaný s Františkem Pavlanem, 25 Apr. 1949, Archiv bezpečnostních složek (ABS), fond (f.) Vyšetřovací spisy, archivní číslo (arch. č.) V-2670/Brno, Operativní materiál, podsvazek (podsv.) 1; Protokol sepsaný s Antonínem Kratinou, 6 July 1949, ABS, f. Vyšetřovací spisy, arch. č. V-2671/Brno, 9-10; Pamětní kniha obce Pozděchova od r. 1924, Státní okresní archiv Vsetín (SOkA Vsetín), f. AO Pozděchov, inventární číslo (inv. č.) 11, 74-5, 82-3.

2 Protokol sepsaný s Antonínem Zichou, 25 Apr. 1949, ABS, f. Vyšetřovací spisy, arch. č. V-2670/Brno, Operativní materiál, podsv. 1; Světlana Jarmila a Makyta - likvidace, 28 Apr. 1949, ABS, f. Vyšetřovací spisy, arch. č. V-2670/ Brno, Operativní materiál, podsv. 1, 53-4.

(c) The Author(s), 2021. Published by Cambridge University Press 
other defendants, stood trial in the nearby town of Vsetín. These men, the prosecutor declared, were members of a conspiratorial network with the enigmatic name of Světlana. ${ }^{3}$

To officials in Czechoslovakia's recently established communist dictatorship, Světlana was a complex organisation run along military lines. On a hand-drawn map of the group's internal structure, the Czechoslovak secret police (Státní bezpečnost; StB), designated Šimara, Šmotek and Kratina as leading members of the 'Světlana Terrorist Group'. ${ }^{4}$ Thin lines in coloured pencil connected them to the partisan leader Josef Vávra-Stařík, who allegedly directed Světlana from his Paris exile, in concert with Western intelligence services. Rudolf Lenhard, Vávra-Stař́k's local lieutenant, had recruited the men into this dangerous network. The brawl in Pozděchov revealed an international conspiracy whose reach extended even into this little village in the hills of eastern Moravia.

Contemporary observers might see Světlana as a paradigmatic example of the third resistance (třetí $o d b o j$ ), a popular framework for understanding opposition during the early years of communist dictatorship in Czechoslovakia. This narrative describes resistance to the communist regime as the third act of a national struggle for freedom from foreign tyranny that began under Austrian rule and continued during Nazi occupation. Světlana's members, participants in both anti-Nazi and anticommunist resistance, might easily symbolise the continuity of Czech democratic opposition to totalitarian repression. ${ }^{5}$ Critics of this framework, however, describe it as a memory project, an attempt to create a usable past for a morally renewed post-communist Czech society. They emphasise the role of police provocation in Světlana and similar 'anti-state conspiracies' of the Stalinist era, explaining the third resistance as the product of political prisoners' internalisation and reinterpretation of a status ascribed to them by a repressive regime. ${ }^{6}$ Further complicating the matter is the ambiguous place of the Soviet-linked anti-fascist partisan movement in Czech memory and historiography. These partisans' key symbolic role in legitimising communist power coloured scholarship prior to 1989 and motivated polemical revision thereafter.

Historians, journalists and researchers have offered varying interpretations of the Světlana network. In books, newspaper articles and television documentaries it has been described as an StB provocation designed to sow terror and repress potential dissent, as the first manifestation of Czechoslovak reform communism and as a patriotic organisation that grew too quickly to maintain its military discipline. ${ }^{8}$ Most recently, an exhibition developed by the Institute for the Study of Totalitarian Regimes

${ }^{3}$ Spis obžalovací, 19 June 1950, ABS, f. Vyšetřovací spisy, arch. č. V-2671/Brno, 3-4.

4 Map, ABS, f. Vyšetřovací spisy, arch. č. V-2670/Brno.

5 See Petr Radosta, Protikomunistický odboj: historický nástin (Prague: Egem, 1993); Zora Dvořáková, 'Třetí odboj protikomunistický, in Jaroslav Cuhra and Václav Veber, eds., Za svobodu a demokracii: Odpor proti komunistické moci (Prague: Evropské hnutí v České republice, 1999); Tomáš Bursík, 'Diskuse nad třetím odbojem', in Odboj a odpor proti komunistickému režimu $v$ Československu a ve střední Evropě (Prague: Ústav pro studium totalitních režimů, 2010), 17-26.

6 Françoise Meyer, Češi a jejich komunismus: Pamět a politická identita (Prague: Argo, 2009), 166-91; Vítězslav Sommer, 'Cesta ze slepé uličky “třetího odboje”. Koncepty rezistence a studium socialistické diktatury v Československu', Soudobé dějiny 14, 1 (2012); Michal Kopeček, 'Czech Republic: From the Politics of History to Memory as Political Language', Cultures of History Forum (Dec. 2013), available at cultures-of-history.uni-jena.de/debates/czech/czech-republic-fromthe-politics-of-history-to-memory-as-political-language (last visited June 2020).

7 See Vladimír Černý, 'Jan Tesař a výzkum partyzánského hnutí v protektorátu', Soudobé dějiny 25, 3-4 (2018).

8 Zdenek Šedivý, Světlana. I. čsl. partyzánská brigáda Jana Žižky z Trocnova ve třetím odboji (Vimperk: 1997); Jaroslav Pospíšil, Hyeny v akci (Vizovice: Lípa, 2003); Lubomír Boháč, 'Partyzáni opět v boji', in Listy 3 (2011), available at listy.cz/archiv.php? cislo=113\&clanek=031108 (last visited June 2020); Tajné akce StB, 'Akce Světlana', directed by Marcel Petrov, aired on 7 Apr. 2009 on ČT1, available at ceskatelevize.cz/ivysilani/10209991308-tajne-akce-stb/409235100221014-akce-svetlana (last visited June 2020); Po stopách třetího odboje, 'Výstřely v parku', directed by Marcel Petrov, aired on 17 Oct. 2011 on ČT2, available at ceskatelevize.cz/porady/10314845897-po-stopach-tretiho-odboje/411235100221008-vystrely-v-parku/ (last visited June 2020). Jaroslav Rokoský discusses the fate of another participant in the Pozděchov attack in 'Ve stínu šibenice. Případ sovětského občana Timofeje Simulenka', Pamět ${ }^{\vee} a$ dějiny, 9, 2 (2015). The first and as yet only complete account of the Světlana case reconstructed through police sources was produced as a bachelor's thesis. See Michaela Lišková, 'Organizace Světlana. Studie o působení protikomunistické odbojové skupiny na Zlínsku v letech 1948-1952', bachelor's thesis, Masaryk University, 2011. 
emphasised the complexities of the Světlana case to illustrate both the internal machinations of the StB and the shifting images of resistance to communist rule. ${ }^{9}$ Světlana received little attention from official mythmakers of the 1970s and 1980s, who turned acts of anti-communist violence into popular entertainment that celebrated the state's victory over its treacherous class enemies. While the more famous Mašín brothers could stand in for the reactionary bourgeoisie, and the Babice murders illustrated the struggle for agricultural collectivisation, Světlana did not provide the late socialist period with natural villains. ${ }^{10}$

This article proposes a new interpretation of Světlana and its place in Czechoslovakia's post-war history. Světlana, I argue, was neither a coherent anti-communist resistance organisation, nor was it simply a trap laid by agents of the regime. Rather, it was a discourse of opposition that enabled both resistance and repression. Through Světlana, dissatisfied former partisans mobilised wartime practices and networks against the consolidating communist regime, while StB agents produced a story of subversion, conspiracy and terror, the detection and prosecution of which illustrated official propaganda and demonstrated the power of the state. Světlana also demonstrates the hidden complexity of popular politics in Czechoslovakia after the Second World War. Its leading members' grievances were rooted in a distinct political ethic that developed through wartime resistance and post-war activism. Those who had defended the nation under occupation, these former partisans believed, held the right to power in the liberated state. This political ethic motivated many of Světlana's members to ally with the Czechoslovak Communist Party (Komunistická strana Československa; KSČ) after liberation, but also inspired their opposition to the new regime following the coup of February 1948.

Světlana was shaped by the specific wartime experiences, social ties, physical geography and local identity of Moravian Wallachia, the rural region at the heart of the network. This case offers an opportunity to examine popular politics in a setting very different from the major cities and borderland areas that have been the focus of much prior research on post-war Czechoslovakia. Before 1989 both Western and Czechoslovak emigrant scholars sought to explain the communists' seizure of power by examining high politics, diplomacy and official institutions. ${ }^{11}$ More recently, historians have placed the rise of the communist regime in the context of Czech cultural and intellectual history, examining how communists and their allies mobilised familiar national narratives and symbols to set the boundaries of acceptable political discourse. ${ }^{12}$ Other studies have addressed how war, occupation and post-war violence made Czechoslovak society more receptive to communist appeals. The swelling

9 See the exhibition's associated publication, Zdeněk Homola et al., Př́pad Světlana. Proměny obrazu třetího odboje (Prague: Ústav pro studium totalitních režimů, 2017).

10 For the Babice case in official popular entertainment, see Michal Stehlík, Babické vraždy 1951 (Prague: Academia, 2016), 223-9; for the Mašín brothers, see Josef Švéda, 'Reprezentace bratří Mašínů jako "nepřátel socialismu” v povídkových souborech z nakladatelství Naše vojsko', Bohemica Olomucensia, 4, 2 (2012). See also Paulina Bren, The Greengrocer and His TV: The Culture of Communism after the 1968 Prague Spring (Ithaca: Cornell University Press, 2010), 74-83. One use of the Světlana case in normalisation-era popular culture can be found in Alois Císař and Ota Holub, Př́běhy věrnosti a cti (Prague: Naše vojsko, 1987). A 1972 episode of the radio program ' $Z$ tajných sejfü', which has evidently been lost, also made use of the Světlana police files. Some aspects of the case appear in the film Cesty mužŭ, also from 1972, where members of a terrorist band called 'Lesana' are captured attempting to escape abroad. See Homola et al., Př́pad Světlana, 60-2.

11 Josef Korbel, The Communist Subversion of Czechoslovakia, 1938-1948 (Princeton: Princeton University Press, 1959); Edward Taborsky, Communism in Czechoslovakia, 1948-1960 (Princeton: Princeton University Press, 1961); Jon Bloomfield, Passive Revolution: Politics and the Czechoslovak Working Class, 1945-1948 (New York: St. Martin's Press, 1979); Martin Myant, Socialism and Democracy in Czechoslovakia, 1945-1948 (Cambridge: Cambridge University Press, 1981); Karel Kaplan, The Short March: The Communist Takeover in Czechoslovakia, 1945-1948 (London: C. Hurst and Company, 1987).

12 Derek Sayer, The Coasts of Bohemia: A Czech History (Princeton: Princeton University Press, 1998); Bradley Abrams, The Struggle for the Soul of the Nation: Czech Culture and the Rise of Communism (Lanham: Rowman and Littlefield, 2004); Melissa Feinberg, Elusive Equality: Gender, Citizenship, and the Limits of Democracy in Czechoslovakia, 1918-1950 (Pittsburgh: University of Pittsburgh Press, 2006); Tara Zahra, Kidnapped Souls: National Indifference and the Battle for Children in the Bohemian Lands, 1900-1948 (Ithaca: Cornell University Press, 2008); Christiane Brenner, Mezi východem a západem: České politické diskurzy 1945-1948 (Prague: Argo, 2015). 
ranks of the working class under Nazi occupation expanded the communists' potential constituency, and expulsion of German speakers from the borderland regions of Bohemia and Moravia provided a blank slate for the creation of new socialist communities. ${ }^{13}$ Despite the importance of rural interests in shaping party strategy and government policy, rural political life outside the ethnically cleansed borderlands has rarely been the subject of close study. The intensely participatory nature of Czechoslovak politics during this period demands a closer examination of the experiences, practices and institutions that shaped politics and society in regions such as Moravian Wallachia.

Historical research on opposition during the early years of communist dictatorship is hindered by a dearth of sources. These resisters wrote far less than the dissidents of later decades, requiring researchers to rely on records produced and compiled by police agents. Světlana offers a uniquely broad source base for reconstructing both historical events and mentalities. Former partisans in Wallachia published books, brochures and periodicals documenting their wartime resistance and presenting their hopes for the post-war order. Village chronicles offer information about everyday life and provide a local perspective on national events. Finally, the extensive official documentation of the Světlana case - including intercepted letters and preserved leaflets, reports from agents and informants, confession statements, interrogation protocols, court proceedings and documents produced during internal investigations of StB practices - reveal how the police and judiciary constructed an international conspiracy from local resistance and dissatisfaction. While a full account of the Svetlana network is beyond the scope of one article, this study traces the events leading to the attack in Pozděchov in April 1949 and the trial in Vsetín in June 1950 through the stories of former partisans Josef Vávra-Stařík, Rudolf Lenhard and Alois Šimara.

\section{Partisan War and People's Democracy in Moravian Wallachia}

In the mid-twentieth century, Moravian Wallachia was a poor, remote region known for its hilly landscape, distinctive folk culture and traditions of rebellion. Writers and ethnographers regretted the locals' backwardness and resistance to change, but admired their 'rough, tenacious, unyielding spirit', shaped by the region's harsh mountain climate. ${ }^{14}$ This spirit had led the Wallachians to rise up against the Habsburg armies during the Thirty Years' War and to defend Moravia against Turkish raids and Hungarian uprisings. ${ }^{15}$ The Second World War seemed to confirm Wallachia's reputation for heroism and defiance. Its terrain and proximity to the Slovak border provided opportunities for resistance from the earliest days of the Nazi occupation. Although post-war reports may be somewhat exaggerated, authorities often failed to prevent local farmers and villagers from maintaining economic ties with their Slovak neighbours, assisting Czechs seeking to escape across the border or hiding their produce from agricultural inspectors. ${ }^{16}$ During the war's final year Allied forces began preparing for an uprising in the occupied Protectorate of Bohemia and Moravia. British-trained parachutists landed near Wallachia in the spring of 1944 and built an underground network whose members included Alois

\footnotetext{
13 Lenka Kalinová, Východiska, očekávání a realita poválečné doby (Prague: Ústav pro soudobé dějiny AV ČR, 2004); Jaromír Mrňka, Svéhlavá periferie: každodennost diktatury KSČ na př́kladu Šumperska a Zábřžska v letech 19451960 (Prague: Ústav pro studium totalitních režimů, 2015); Eagle Glassheim, Cleansing the Czechoslovak Borderlands (Pittsburgh: Pittsburgh University Press, 2016); Matěj Spurný, Most do budoucnosti: Laboratoŕ socialistické modernity na severu Čech (Prague: Karolinum, 2016); David Gerlach, The Economics of Ethnic Cleansing: The Transformation of the German-Czech Borderlands after World War II (Cambridge: Cambridge University Press, 2017).

14 Metoděj Jahn, 'Povaha Valachů', in Lidová čitanka moravská, ed. František Bílý (Telč: Emil Šolc, 1907), 408.

15 Miroslav Válka, 'Valašsko a jeho lidová kultura v národopisné publicistice a odborné literatuře', in Svatava Urbanová, Lumír Dokoupil, Jakub Ivánek and Petr Kadlec eds., Valašsko: Historie a kultura (Ostrava: Filozofická fakulta Ostravské univerzity, 2014), 15-24.

16 Obecní kronika 1924-1955, Státní okresní archiv Zlín (SOkA Zlín), f. MNV Újezd, inv. č. 1, 60-1, 64-5; Pamětní kniha obce Nedašova Lhota, SOkA Zlín, f. AO Nedašova Lhota, inv. č. 1, 80-4, 88-9, 92-3, 104; Pamětní kniha obce Vys. Pole, SOkA Zlín, f. ObÚ Vysoké Pole, inv. č. 2, 59-60; Pamětní kniha obce Prlova, SOkA Vsetín, f. AO Prlov, inv. č. $13,73,85-6$.
} 
Šimara and Rudolf Lenhard. ${ }^{17}$ That September the partisans of the Soviet-trained First Czechoslovak Partisan Unit (later Brigade) of Jan Žižka, among them Josef Vávra-Stařík, crossed into Moravia from Slovakia. ${ }^{18}$ Although Nazi repression and infiltration prevented both partisans and parachutists from establishing the organisational infrastructure to support a mass uprising, small groups of rebels remained in the Wallachian hills. After the British-linked network collapsed at the end of 1944 Šimara and Lenhard joined a branch of the Jan Žižka Brigade. ${ }^{19}$ Sheltering with local farmers, partisans sabotaged transportation and communication infrastructure, attacked and disarmed retreating soldiers and distributed leaflets calling for resistance. ${ }^{20}$ As the front drew closer and anti-partisan forces were called to the area, the people of Wallachia found themselves in a zone of increasing violence. ${ }^{21}$ On 19 April 1945 SS forces razed Ploština to the ground, forcing twenty-four villagers to their deaths in the flames. Further massacres at Leskovec, Prlov, Lačnov and Hovězí left over sixty dead. ${ }^{22}$

Liberation in May 1945 restored Czechoslovak independence, but it did not re-establish the political system that existed prior to the Munich Agreement. Deeply suspicious of the interwar republic's political and ethnic pluralism, political and intellectual leaders developed a radical vision of national unity, political equality and popular participation - a 'people's democracy'. Political power would be concentrated in the National Front, a coalition of centre-left and left-wing parties. Ethnic minorities would be expelled or assimilated, and collaborators punished and purged from public life. Large sections of the nation's industry would be brought under state control. ${ }^{23}$ The Košice Government Programme, the agreement between the KSČ leadership and representatives of the Czechoslovak government in exile, served as the foundation of this new order. It called for the wholesale replacement of existing municipal and village governments by National Committees, local councils organised and led by 'those who have proven themselves in the struggle against foreign invaders and traitors'. National Committees would form the foundation of the post-war order, enabling all honourable citizens to take part in rebuilding the republic. ${ }^{24}$

Members of the anti-fascist resistance were entrusted with implementing this post-war revolution. In some regions the revolution brought about the destruction of social ties and local communities. Post-war violence ended multiethnic coexistence in the Bohemian lands' urban centres and uprooted the German population of the northern, western and southern borderlands. Some members of underground resistance groups, as well as opportunists whom one writer described as 'me-too partisans',

17 Radomír Kunc, Clay-Eva volá Londýn (Perth Amboy: Universum Sokol Publications, 1977), 339-40.

18 Vladimír Černý, 'Protipartyzánské operace na Moravě v letech 1944-1945', PhD thesis, Masaryk University, 2007, 78-116; Protokol sepsaný s Josefem Vávrou-Staříkem, 21 Mar. 1947, ABS, f. Vyšetřovací spisy, arch. č. V-2671/Brno, $1-2$.

19 Protokol sepsaný s Aloisem Šimarou, 22 June 1949, ABS, f. Vyšetřovací spisy, arch. č. V-2671/Brno, 2; Protokol sepsaný s Rudolfem Lenhardem, 25 May 1949, ABS, f. Vyšetřovací spisy, arch. č. V-2670/Brno, 1.

20 Detlef Brandes, Češi pod německým protektorátem: okupační politika, kolaborace a odboj 1939-1945 (Prague: Prostor, 1998), 415-33; Černý, 'Protipartyzánské operace na Moravě’, 169-81, 222-6; Václav Kural and Zdeněk Štěpánek, České národní povstání v květnu 1945 (Prague: Nakladatelství Karolinum, 2008), 30-41; Marie Hrošová, Na každém kroku boj: historie 1. československé partyzánské brigády Jana Žižky (Vsetín: Česky svaz bojovníku za svobodu, 2012), 276-7, 281-336.

21 Jaromír Mrňka, Limity lidskosti. Politika a sociální praxe kolektivního násilí v českých zemích 1944-1946 (Prague: Ústav pro studium totalitních režimů, 2019), 111.

22 Černý, 'Protipartyzánské operace na Moravě', 222-6; Jiří Padevět, Krvavé finále: Jaro 1945 v českých zemích (Prague: Academia, 2015), 601-6, 611-77, 619-23, 628-9.

23 See Myant, Socialism and Democracy, 54-93; Kaplan, The Short March, 7-17, 33-49; Abrams, The Struggle for the Soul of the Nation, 47-52; Kalinová, Východiska, očekávání a realita, 25-50; Karel Kaplan, Národní fronta 1945-1960 (Prague: Academia, 2012), 9-31; Christiane Brenner, Mezi východem a západem, 39-48, 82-100.

24 'Program nové československé vlády národní fronty Čechů a Slováků', in Jiří Grospič, Jaroslav Chovanec and Juraj Vysokaj, Košický vládní program - budování lidově democratického Československa (Prague: Státní pedagogické nakladatelství, 1977), 128. See also Karel Bertelmann, Vývoj národních výborů do Ústavu 9. května (Prague: Československé akademie ved, 1964), 93-133. 
participated in violence against both German soldiers and German speaking civilians. ${ }^{25}$ The tightlyknit, overwhelmingly Czech villages of Wallachia, however, offered fewer opportunities for retribution. ${ }^{26}$ Partisan leaders called for the restoration of normal order and denounced disruptions of national discipline,. ${ }^{27}$ Former fighters in this region used new political institutions to claim power. In Rudolf Lenhard's native village of Horní Lideč partisans and other locals founded a National Committee one day before the arrival of the Red Army, while in Vsetín, partisans made up half of the town's new leadership. ${ }^{28}$

Czechoslovakia's new government understood partisans as allies in the establishment of a secure national state. The Czechoslovak army promised to recognise partisan military ranks and honours, and former fighters received preferential access to property seized from Germans and collaborators. ${ }^{29}$ Former partisans filled the ranks of the new security services. ${ }^{30}$ The Association of Czech Partisans (Sdružení českých partyzánů; SČP) defended partisans' political interests at the national level. Its chairman was KSČ General Secretary Rudolf Slánský, and other leaders included high-ranking members of the Czechoslovak armed forces and police. In a September 1945 speech Slánský recounted a story of national liberation in which the partisan movement played a leading role. Czechoslovakia had been betrayed by its Western allies and its own ruling classes, who sacrificed the state's independence to preserve their power, he claimed. Fearing the revolutionary potential of common struggle, bourgeois politicians encouraged collaboration, quietism or passive resistance at best. The partisan movement, Slánský argued, brought both national liberation and social revolution. ${ }^{31}$ Partisans now appointed themselves guardians of people's democracy. As one leader declared, former fighters must come to understand the laws of the land as well as they had once known the trees in the forest. ${ }^{32}$

In Wallachia, commemorations of fallen partisans and victims of Nazi atrocities served as celebrations of renewed independence and confirmations of the new order. They also offered an opportunity to place this peripheral region at the centre of a national narrative. Members of the Jan Žižka Brigade worked with prominent villagers to organise a memorial ceremony at Ploština in August 1945, where army general Miloš Žák and deputy prime minister Josef David awarded the massacre's victims with official state medals. ${ }^{33}$ A delegation travelled to Prague before the ceremony to make arrangements with leading national politicians, stopping to place photographs of Wallachian resistance and suffering

25 Pamětní kniha obce Prlova, SOkA Vsetín, f. AO Prlov, inv. č. 13, 137. See Benjamin Frommer, National Cleansing: Retribution against Nazi Collaborators in Postwar Czechoslovakia (Cambridge: Cambridge University Press, 2005), 49-51; Chad Bryant, Prague in Black: Nazi Rule and Czech Nationalism (Cambridge: Harvard University Press, 2007), 236-8; Mrňka, Limity lidskosti, 213-7.

26 In the most recent Czechoslovak census, taken in 1930, 167 of 42,422 residents of the Vsetín district and 75 of 24,341 residents of the Valašské Klobouky district declared German nationality. See Sčitání lidu v republice Československé ze dne 1. prosince 1930: Díl I (Prague: Státní úřad statistický, 1934), 76, 78. A work cataloguing sites of post-war violence in the Bohemian lands lists nine locations in the contemporary Zlín region, two of which were in Wallachia, as compared with thirty-five in the neighboring South Moravian region and seventy-one in the city of Prague. See Jiří Padevět, Krvavé léto 1945: Poválečné násilí v českých zemích (Prague: Academia, 2015). Some partisans from eastern Moravia did participate in retributive violence elsewhere in the country, as described in Mrňka, Limity lidskosti, 252-3.

27 'Rušitelé národní kázně budou potrestáni tvrdě a nemilosrdně', Průlom: list valašského lidu, 23 June 1945, 1.

28 Kronika obce Horní Lideč, SOkA Vsetín, f. MNV Horní Lideč, inv. č. 1, 175, 178; 'Ze schůzi národního výboru na Vsetíně, Partyzán (Vsetín), 15 May 1945, 2.

29 'Dekret presidenta republiky ze dne 20. července 1945 o osídlení zemědělské půdy Němců, Madarů a jiných nepřátel státu českými, slovenskými a jinými slovanskými zemědělci', in Karel Kaplan and Karel Jech, Dekrety prezidenta republiky, díl I (Brno: Doplněk, 1995), 331-5; 'Program nové československé vlády národní fronty Čechů a Slováků', in Grospič, Chovanec, and Vysokaj, Košický vládní program - budování lidově demokratického Československa, 126.

30 Molly Pucci, 'A Revolution in a Revolution: The Secret Police and the Origins of Stalinism in Czechoslovakia', Eastern European Politics and Societies, 32, 1 (Feb. 2018), 9-10.

31 Rudolf Slánský, 'Naši partyzáni', Partyzán, 28 Oct. 1945, Muzeum jihovýchodní Moravy (MJVM), f. ČSPB-OV Gottwaldov, inv. č. H939, 3-6.

32 Address at SČP convention by Miroslav Pich-Tůma, 20 Apr. 1946, Národní archiv, f. KSČ - Ústřední výbor 1945-1989, Praha - Rudolf Slánský, svazek 16, archivní jednotka 172, 28. See also Ema Sateyová, 'Major Šrám o čsl. partyzánech', Partyzán, 20 Sept. 1945, MJVM, f. ČSPB-OV Gottwaldov, inv. č. H939, 2-4.

33 'Památce statečných pasekářů', Čin, 21 Aug. 1945, 2; 'Obnovená československá jednota', Slovo národa, 21 Aug.1945, 1. 
in a prominent building on Wenceslas Square. Survivors subsequently received donations from across the country, including one from young people in a village near Brno who performed a play set in Wallachia to raise money for the rebuilding of Ploština: 'we decided to show our citizens a scene from the lives of the poor, but proud, good and most importantly genuinely Czech hill farmers from our beautiful Wallachia', they wrote. ${ }^{34}$ Locals' relationship to the partisan movement may have been complex during wartime, but after liberation they became fellow combatants in the cause of national freedom. Through their identification with the partisans, the people of Wallachia served as symbols of Czech heroism. ${ }^{35}$

The region's sacrifices under occupation legitimated its political and economic interests. At the Ploština memorial ceremony, high-ranking state officials promised local authorities assistance with rebuilding and modernisation efforts. The National Committee of the village of Vysoké Pole, on whose territory Ploština was located, cited these promises in a petition to the Ministry of Agriculture, which owned a property that the village hoped to repurpose as a library and cultural centre. Echoing long-standing tropes about the region, the writers explained that their citizens had long suffered from alcoholism, poverty and backwardness. Their support of the partisan movement demonstrated their worth as citizens and earned them the right to state assistance. ${ }^{36}$ While local officials argued that the region's improvement served as a moral test for the new government, partisan publications presented the Wallachian village as a model for post-war Czechoslovak society. The mountains had been a refuge for oppressed lovers of freedom since time immemorial, wrote Jan Kobzáň, an artist and folklorist active in the partisan movement. The urban bourgeoisie had passively accepted occupation, but the people of Wallachia acted to preserve their honour and ideals. They may have been poor, but they were not backward. The society of the hills preserved 'a desire for true equality, justice and true human freedom, as the popular government of today understands it - real, true, unfalsified democracy. ${ }^{37}$ Nazi brutality, Rudolf Lenhard wrote, could never subject the 'free sons of the mountains and forests' to its control. The Wallachian people - and the Wallachian landscape itself - rejected the occupiers and embraced the partisans: 'in vain [the Germans] sent specially trained units to fight the partisans, in vain they sent informants. The mountains and their inhabitants did not betray. ${ }^{38}$ Such rhetoric recast Slánskýs arguments in distinctly local terms, presenting the people of Wallachia as exemplary Czechoslovak patriots.

Partisans transformed networks of resistance into tools of local political and economic power. Members of the Jan Žižka Brigade, led by Josef Vávra-Stařík, founded the workers' cooperative Partkol in Zlín, an industrial city at the southwestern edge of the Wallachian region. After briefly serving as the head of Zlín's National Committee, reportedly at the Red Army's request, Vávra-Stařík had emerged as a leading figure among local partisans. ${ }^{39}$ Under his direction Partkol organised folk artists and craftspeople in eastern Moravia and Slovakia, using its profits to aid former partisans and their families. The cooperative maintained the partisan movement's ties to the rural communities that had sustained them during the war. It also represented a peacetime continuation of the partisans' patriotic struggle. Partisans were now 'work[ing] for the republic just as well as they had fought for it',

\footnotetext{
34 Zpráva delegátů vyslaných do Prahy, 29 July 1945, SOkA Zlín, f. MěstNV Val. Klobouky, inv. č. 185, 15-9; letter from SČM Kovalovice u Brna, SOkA Zlín, f. MěstNV Val. Klobouky, inv. č. 185, 8.

35 See also 'Ploština, obětovaná valašská osada', Rovnost, 22 July 1945, 4; Vincenc Nečas, 'Zmučená vesnice’, Rudé právo, 19 Aug. 1945, 3; Ladislav Frajt, 'Únik z plamenného hrobu', Rovnost, 2 Sept. 1945, 3; František Omelka, Blesky nad Beskydami (Brno: Komenium, 1947); Vladimír Růčka, Ploština žaluje! Historie odboje a utrpení valašské paseky, SOkA Zlín, f. FÚ Újezd, inv. č. 111.

36 Letter from Vysoké Pole National Committee to Ministry of Agriculture, 16 Jan. 1947; letter from Vysoké Pole National Committee to Ministry of Agriculture, 18 Oct. 1947, SOkA Zlín, f. MNV Vysoké Pole, inv. č. 77.

37 J. Kobzáň, 'I zastavil trám z plamenů a začal hřímat jako osud', ABS, f. Vyšetřovací spisy, arch. č. V-2670 Brno, 'Národopisná Morava' - 'Světlana', historický původ, 4. See also Jan Kobzáň, 'Hory a uskutečněná živá idea lidu', Partyzán, 5 Dec. 1945, MJVM, f. ČSPB-OV Gottwaldov, inv. č. H939, 3-5.

38 Ruda Lenhart (Rudolf Lenhard), 'Vznik a činnost partyzánského hnutí na Valašsko-kloboucku', ABS, f. Vyšetřovací spisy, arch. č. V-2670 Brno',Národopisná Morava' - 'Světlana', historický původ, 2.

39 Zápis o ustavující schůzi Národního výboru ve Zlíně, 12 June 1945, SOkA Zlín, f. AM Zlína, inv. č. $203,1$.
} 
read an article in the SČP’s official magazine, Partyzán. ${ }^{40}$ Partkol became a social and organisational centre for former fighters in the region. The local partisan movement sponsored exhibitions, concerts, theatre productions, football tournaments and competitions in 'defensive fitness'. ${ }^{41}$

While insisting on their independence, partisan leaders allied themselves closely with the KSČ. Vávra-Stařík declared that his wartime experience had convinced him of the need for social revolution: 'the fight for national liberation was in reality the great struggle of the proletariat, and the capitalist classes stood aside... . Only the poor man, the proletarian, shared his bread with us. ${ }^{, 2}$ Although non-communists fought as partisans, Partyzán explained, the KSČ provided the initiative for armed resistance. Local branches of the SČP echoed communist demands for harsh punishment of accused collaborators, while Partyzán published articles extolling the accomplishments of the Soviet Union and its leaders. ${ }^{43}$ Partisans' prominence in local public life enabled significant gains for the KSČ in the 1946 parliamentary elections. The communists' results in eastern Moravia may appear underwhelming when compared with their extraordinary victories in the Czech borderlands and industrial centres, but they represent a success in a region that had never been a bastion of communist support. ${ }^{44}$ 'The Wallachian region loves our party', exulted the Zlín Communist newspaper Naše pravda, attributing their victory in the Vsetín district first and foremost to 'the heroic traditions of the partisan resistance to the Germans, ${ }^{45}$

The partisan movement brought the radical politics of popular democracy to Moravian Wallachia, providing a model of common sacrifice linked to local society and traditions. 'Unified in resistance, we must be unified in the construction of a new state', declared one former partisan turned district official. 'We will not allow anyone to suffer from hunger and cold in our land. We will not allow the fruits of human labour to remain an object of exploitation... . Wallachians! We have won the war - now [we must] win the peace! ${ }^{46}$ Former partisans demanded that Wallachian sacrifices be honoured not only with ceremonies and medals, but also by accounting for local interests at the highest levels of power. No longer simply an impoverished backwater, Wallachia had become a site of national martyrdom and victory. The influential, self-confident partisan movement secured the region's new position in the Czechoslovak state.

\section{The Battle for Honour and Power}

Despite the promises of officials in Prague and the hopes of local leaders, reconstruction proceeded with difficulty during the post-war period. The National Committee chairman from the remote village of Nedašova Lhota was regularly required to make a long journey by bicycle on pitted roads to the district capital of Uherský Brod, returning laden with ration coupons to be distributed among his

\footnotetext{
40 'Poctivé lidové umění všem', Naše pravda, 9 Oct. 1945, 2; 'Sněmování partyzánư', Partyzán, 24 Dec. 1945, MJVM, f. ČSPB-OV Gottwaldov, inv. č. H939, 6; František Jurča, 'Partyzáni se snaží o uplatnění i v míru', Tep nového Zlína, 23 Jan. 1946, 3; Ema Seteyová-Foltýnová, 'První v boji - první v práci’, Partyzán, 21 June 1946, 14-5; 'Partkol: mírové dílo partyzánů’, Partyzán, 10 Jan. 1947, 21.

41 Sdruzení českých partyzánů, okresní odbočka ve Zlíně vypisuje I. ročník partyzánského závodu v branné zdatnosti, Aug. 1946, MJVM, f. ČSPB-OV Gottwaldov, inv. č. H5881; Oběžník č. 3, 25 June 1947; Oběžník č. 5, 16 July 1947, SOkA Vsetín, f. SNR-OV Valašské Meziřičí, inv. č. 20; 'Instrukční středisko SČP ve Zlíně', 'Krajsky divadelní kolektiv PARTYZÁN ve Zlíně’, Partyzán, 10 Jan. 1947, 17, 18.

42 'Pozdrav našich partyzánů', Naše pravda, 30 May 1945, 4.

43 'Vladimír Iljič Lenin, 24.I.1924', Partyzán, 18 Jan. 1946, 12-3; 'Generalissimus Stalin: Sovětský režim předčí všechny režimy světa', Partyzán, 15 Feb. 1946, 8; 'K VIII. sjezdu KSČ', Partyzán, 29 Mar. 1946, 1-2; 'Rok na kolchoze v dalekém Kazachstánu', Partyzán, 17 May 1946, 9; 'Význačná krajská konference SČP ve Zlíně’, Partyzán, 21 June 1946, 11.

44 The Zlín region, where Wallachia is located, was the only administrative region in the Czech lands where the KSČ did not take first place among the four Czech parties of the National Front. See Český statistický úrad, 'Výsledky voleb do Národního shromáždění v roce 1948 na území České republiky', available at czso.cz/documents/10180/20536128/ 422008k018.pdf (last visited June 2020).

45 'Valašský kraj miluje naši stranu', Naše pravda, zvláštní vydání, 27 May 1946, 1.

46 Sokol Stalinský, 'Valašský lide!’ Partyzán (Vsetín), 8 May 1945; 'Soudruh Alois Havlík', Průlom, 29 Sept. $1945,1$.
} 
citizens. Residents of Nedašova Lhota also complained that they received little in compensation for property destroyed or stolen by retreating soldiers, while those in a neighbouring village received payments despite having seen no war damage. ${ }^{47}$ Many young workers left Wallachia for the ethnically cleansed borderlands, among them Alois Šimara, who took over management of a tobacco shop in the northern Moravian town of Hanušovice. ${ }^{48}$ While their departure eased the difficult housing situations in many villages, it also disrupted local social life and political administration. Agricultural policies put in place under occupation continued after liberation, and local police officers devoted much of their time to suppressing the black market. ${ }^{49}$ In 1947 a catastrophic drought disrupted the harvest and forced farmers to sell off their cattle for lack of fodder. ${ }^{50}$

Partisans had their own particular grievances in the new order. The new republic, they complained, had not made a sufficiently radical break with its past. Reactionaries and collaborators lurked within the state administration, waging bureaucratic war against people's democracy and its partisan defenders. Partyzán published complaints from around the country: civil servants friendly to the Nazi occupiers remained in their jobs, courts treated accused traitors too leniently and local officials in the borderlands did not respect partisans' preferential access to confiscated property. ${ }^{51}$ Zlín district authorities refused to issue Partkol a necessary trade certificate: 'partisans in Zlín have too much information about certain public officials, hence the never-ending attempts to thwart them', one local partisan wrote. ${ }^{52}$ The SČP even charged that fighters were being prosecuted and jailed for acts of wartime resistance. ${ }^{53}$ 'Reaction is dangerously rearing its ugly head. With the help of gold and the old bureaucratic system, it is attempting to destroy and besmirch our work', read a declaration issued by the Ploština branch of the SČP. ${ }^{54}$

Former partisans in Wallachia did not trust the movement's Prague-based leaders to protect their interests. The region's remoteness and peripheral status had made it an ideal base for partisan warfare in the occupied Bohemian lands. But after liberation local partisans found that their distance from centres of political power marginalised them within the SČP. Josefa Slánská, the wife of Rudolf Slánský, recalled that Moravian complaints of underrepresentation in the group's leadership nearly provoked a shoot-out at its first convention. ${ }^{55}$ 'We don't have the time for hunting down sinecures like they do in Bohemia. Today we're beaten for everything and the Praguers have licked off all the cream', wrote Vávra-Stařik. ${ }^{56}$ As he later explained under interrogation, rank-and-file members were suspicious of the military officers in the SČP's Central Committee, whom they did not regard as true partisans. A movement for popular, democratic resistance had been taken over by 'lords' interested only in furthering their own political careers. ${ }^{57}$ More Bohemian than Moravian partisans had received official recognition, entitling them to state benefits, Vávra-Stařík publicly complained.

47 Pamětní kniha obce Nedašova Lhota, SOkA Zlín, f. AO Nedašova Lhota, inv. č. 1, 107, 128.

48 Protokol sepsaný s Aloisem Šimarou, 22 June 1949, ABS, f. Vyšetřovací spisy, arch. č. V-2671/Brno, 2. See also Miloslav Šerý, 'Osídlení pohraničí severní Moravy a Slezska po 2. světové válce obyvatelstvem Valašskokloboucka', master's thesis, Palacký University, 2008.

49 See Velitelství SNB Vlachovice, staniční služební kniha od roku 1947, ABS, f. N7, inv. č. 112.

50 Pamětní kniha obce Vys. Pole, SOkA Zlín, f. ObÚ Vysoké Pole, inv. č. 2, 90; Pamětní kniha obce Pozděchova od r. 1924, SOkA Vsetín, f. AO Pozděchov, inv. č. 11, 66-7; Pamětní kniha obce Bratřejova, SOkA Zlín, f. AO Bratřejov, inv. č. 91/72, 71.

51 'Jak je to možné?', 'Fašista bude vyučovat?' Partyzán, 18 Jan. 1946, 4; 'Krajský soud v Novém Jičíně neprojednává všechny př́pady zrady', 'Udala devět Čechů gestapu a nikdo ji nechce soudit', Partyzán, 7 June 1946, 4; 'Kde je vina?', Partyzán, 22 Nov. 1946, 4; 'Platí zákon o přednostním právu?', Partyzán, 24 Jan. 1947, 6.

52 “"Vzorné porozumění” k partyzánům ve Zlíně’, Partyzán, 2 Aug. 1946, 21.

53 'Orgány ministerstva spravedlnosti vězní bojovníky za svobodu', Rudé pravo, 26 June 1947, 1. See also 'Agitace s partyzány', Svobodné slovo, 28 June 1947, 2; 'Agitace s partyzány, neboli operace se podařila, pacient zemřel', Partyzán, 4 July 1947, 5.

54 'Prohlášení partyzánské skupiny “Ploština”, Partyzán, 1 Oct. 1945, MJVM, f. ČSPB-OV Gottwaldov, inv. č. H939, 5.

55 Josefa Slánská, Report on My Husband (New York: Atheneum, 1969), 129.

56 Letter from Josef Vávra-Stařík, 9 Jan. 1947, ABS, f. A8/1, inv. č. 1365, podsv. 3.

57 Zápis o výpovědi - Josef Vávra-Stařík, 25 Jan. 1951, ABS, f. Vyšetřovací spisy, arch. č. V-2646 MV, podsv. 9, 2-5. 
Wallachian homes and farms destroyed in Nazi retributive campaigns remained in disrepair. At a meeting in Zlín in late 1946 local partisans confronted Augustin Schramm, a member of the SČP's Central Committee and head of the KSČ Central Committee's partisan section. Over Schramm's strenuous objections they resolved to take matters into their own hands. In a letter to the Ministry of National Defence they called for improved career and educational opportunities, the recognition of partisan military ranks and social welfare for disabled partisans and the widows and orphans of fallen fighters. If the government did not fulfil its obligations, the partisans declared, they would take to the hills. 'This was meant only academically, not practically, and not as a serious threat... of armed resistance', explained Vávra-Stařík when questioned by the police, further denying the allegation that he had advocated partisans resort to 'more drastic means' to achieve their goals. ${ }^{58}$

Power struggles within the partisan movement were expressed as battles over wartime honour. Vávra-Stařík's murky past provided his rivals with ample material for accusations of disloyalty and opportunism. ${ }^{59}$ He had been a prominent member of Národopisná Morava, a folklore association which later became an organ of collaboration. After the Nazi occupation of the Bohemian lands, Vávra-Staŕík campaigned for southeastern Moravia to be attached to newly independent Slovakia. ${ }^{60}$ Furthermore, Vávra-Stařík's departure from the Zlín National Committee was precipitated by a letter by a former neighbour who claimed that the partisan leader had been responsible for his denunciation to the Gestapo. ${ }^{61}$ The Zlín branch of the SČP defended Vávra-Stařík, arguing that he had acted in Národopisná Morava as an agent of anti-fascist resistance. He had 'demonstrated merit like few others in the liberation of the Czechoslovak Republic', they declared. ${ }^{62}$ Vávra-Stařík and his friends held Augustin Schramm responsible for these attacks on his partisan honour. They charged that Schramm was abusing his position on the state partisan verification commission to eliminate his rivals and consolidate his own power through intrigue and blackmail. Vávra-Stařík's genuine popularity and influence within the movement, his allies argued, had made him a target of Schramm's intrigue and manipulation. ${ }^{63}$

In the years following liberation the post-war vision of national unity and common struggle was crumbling both within the partisan movement and throughout the country. By February 1948 tensions domestic as well as international had brought Czechoslovakia to political crisis. ${ }^{64}$ At a mass demonstration in Prague, Communist Party leader Klement Gottwald called on citizens to form 'action committees' that would carry out the thorough cleansing that the partisans had long demanded. ${ }^{65}$ After a

58 'Partyzáni proti šmelinářům', Naše pravda, 18 Dec. 1946, 5; Report to Ministry of the Interior, division VII., 26 Feb. 1947, ABS, f. Vyšetřovací spisy, arch. č. V-2646 MV, podsv. 4; Protokol sepsaný s Josefem Vávrou-Staříkem, 21 Mar. 1947, ABS, f. Vyšetřovací spisy, inv. č. V-2671/Brno, 3-6. The Naše pravda article describes a meeting attended by Schramm in December 1946, while the police report describes a similar meeting at which a different representative of the SČP Central Committee was present.

59 Accusation against Josef Vávra-Stařík sent by Ministry of National Defense to Ministry of Interior, 2 Aug. 1947, ABS, f. 306, signatura $68 / 6,1-3$.

60 See František Mezihorák, Hry o Moravu: Separatisté, iredentisté, a kolaboranti 1938-1945 (Prague: Mladá Fronta, 1997); Ivo Pejčoch, Fašismus v českých zemích, 1922-1945 (Prague: Academia, 2011), 251-63.

61 Letter from Dubňany National Committee to Zlín National Committee, 14 May 1945, ABS, f. Vyšetřovací spisy, arch. č. V-2646 MV, podsv. 3; letter from Antonín Koštoval to Zlín National Committee, 5 June 1945, ABS, f. Vyšetřovací spisy, arch. č. V-2646 MV, podsv. 3; Zápis ze schůze národního výboru Velkého Zlína, 15 June 1945, SOkA Zlín, f. AM Zlína, inv. č. 203, 45. Under interrogation, Vávra-Stařík denied having ever collaborated with the Gestapo. See Akce 'Stařeček Podzim', Svodka ze dne 21. března 1950, 21 Mar. 1950, ABS, f. Vyšetřovací spisy, arch. č. V-2646 MV, podsv. 12.

62 Vyšetřovací zpráva a posudek vyšetřovací komise pověřené usnesením partyzánského sjezdu konaného v Uh. Hradišti, 15 July 1947, ABS, f. 306, sign. 68/6, 4-15; Resolution by SČP Zlín regional secretariat, 26 Aug. 1947, ABS, f. 306, sign. 68/6.

63 Úrední záznam sepsaný s IP-14 dne 6. července 1947 ve St. Městě, 8 July 1947, ABS, f. Vyšetřovací spisy, V-2670/Brno, Operativní materiál, podsv. 1, 83; Úrední záznam - vlastní, dne 7. srpna 1947 v Babicích u Uh. Hradiště, 8 Aug. 1947, ABS, f. Vyšetřovací spisy, V-2670/Brno, Operativní materiál, podsv. 1, 84.

64 For the February 1948 crisis see Myant, Socialism and Democracy, 181-219; Karel Kaplan, The Short March, 174-88; Kevin McDermott, Communist Czechoslovakia, 1945-89: A Political and Social History (New York: Palgrave, 2015), 54-7.

65 'Hlas skutečné Národní fronty na historickém táboru lidu na Staroměstském náměsti', Rudé právo, 22 Feb. 1948, 1-2. 
communist-dominated government was confirmed on 25 February, action committees enabled the consolidation of a new regime. These committees were set up at all levels of governance, as well as in universities, sports clubs, professional associations and voluntary organisations, transforming independent institutions into mechanisms for the extension of the KSČ's power. ${ }^{66}$

Action committees also provided local functionaries with an opportunity to settle old scores. When the KSČ newspaper Rudé právo called for a purge of the partisan movement on 10 March Vávra-Stařík attempted to form an action committee for the Zlín district branch of the SČP. Instead, he found himself stripped of his leadership position and expelled from the organisation. ${ }^{67}$ After receiving word that a warrant had been issued for his arrest, Vávra-Starík fled the country with three of his partisan comrades. ${ }^{68}$ Later that spring Augustin Schramm was shot dead in his apartment. Police arrested a young man who had recently returned to Czechoslovakia from a German refugee camp, where he had met Vávra-Staŕík. Newspapers announced that the Zlín partisans had established a 'terrorist band' with the help of US intelligence and reactionary émigrés. They had allegedly sent an assassin to Prague to murder their old rival, sending a signal to foreign agents to begin the counterrevolution. In the fall of 1948, during one of Czechoslovakia's first political show trials, Vávra-Stařík was sentenced to death in absentia. $^{69}$

After settling in Paris, Vávra-Staŕík quickly found himself alienated from the anti-communist Czechoslovak émigré community then establishing itself in the West. In letters intercepted by the StB he accused exiled politicians of plotting to restore the power of wealthy landlords and industrialists, wasting time with minor factional squabbles and disregarding the interests of ordinary Czechoslovaks both at home and in emigration. Vávra-Stařík and his partisan comrades established a group to defend their socialist views, which they named after his young daughter, Světlana. Under interrogation Vávra-Stařík explained that he had sought to extend this political network back into Czechoslovakia through his associate, the former partisan Antonín Slabík. Support at home, he hoped, would both strengthen his position in Paris and prevent émigré leaders from returning to power. ${ }^{70}$

The communist dictatorship allowed the partisan movement to maintain its institutions and honour at the expense of its independent power. The SČP and the Jan Žižka Brigade issued resolutions condemning Vávra-Stař́k as a traitor to 'the most sacred partisan ideals.$^{71}$ For some partisans, however, the KSČ's coup only compounded their grievances against the state. When Vávra-Stařík contacted his associates in Czechoslovakia and informed them that he had set up a secret political network, some saw an opportunity to reprise their roles as liberators.

66 Jaroslav Mlýnský, Únor 1948 a akční výbory Národní fronty (Prague: Academia, 1978), 32-92; Karel Kaplan, Národní fronta 1948-1960, 35-9, 46-68.

67 'Očista od falešných “odbojářư”, Rudé právo, 10 Mar. 1948, 2; 'Očista mezi partyzány', Naše pravda, 11 Mar. 1948, 5; Kaplan, Národní fronta, 283n7.

68 Zápis o výpovědi - Josef Vávra, 25 July 1950, ABS, f. A8/1, inv. č. 1365, podsv. 2, 1-2; Protokol o svědecké výpovědi sepsané dnešního dne s Josefem Vávrou-Staříkem, 12 Sept. 1950, ABS, f. A8/1, inv. č. 1365, podsv. $2,1$.

69 'Odhalení teroristických a spionážních skupin, vyslaných do ČSR americkou zpravodajskou službou', Rudé právo, 18 July 1948, 1-2; 'Vrah majora A. Šramma ve středu před státní soud', Rudé právo, 31 Oct. 1948, 1; 'Český komitét chtěl roznítit v Československu povstání, Naše pravda, Nov. 4, 1948, 1-2; "Vrahové majora Šramma odsouzeni k trestu smrti,” Rudé právo, 26 Nov. 1948, 1. See also Šárka Rokosová, 'Př́ípad Miloslav Choc a spol'., Securitas imperii, 12 (2005). Vávra-Stařík denied having taken part in the murder multiple times. See Vlastnoruční opis S./Staříka-Vávry/ z ciziny Václavu Šustrovi v Praze, 15 July 1948, ABS, f. Vyšetřovací spisy, arch. č. V-2646 MV, podsv. 4; Report written by J. Šindelář, 19 Nov. 1949 , ABS, f. Vyšetřovací spisy, arch. č. V-2646 MV, podsv. 4; Dosavadní výslech a plán dalšího výslechu V-S, 11 Jan. 1950 , ABS, f. Vyšetřovací spisy, arch. č. V-2646 MV, podsv. 11, 2.

70 Document 1 attached to Interior Ministry report regarding Josef Vávra-Stařík's correspondence, 12 Nov. 1948, ABS, f. Vyšetřovací spisy, arch. č. V-2646 MV, podsv. 4, 98; Letter sent by Martin Válek (Josef Vávra-Stařík) to Jarmila Kačerlová, 27 May 1949, ABS, f. A8/1, inv. č. 1365, podsv. 4; Protokol sepsaný s Josefem Vávrou, 8 Feb. 1950, ABS, f. A8/1, inv. č. 1365, podsv. č. 2, 2-6; Zápis o výpovědi sepsaný zdějším velitelstvím s obviněným Josefem VávrouStaříkem, 23 Oct. 1950, ABS, f. A8/1, inv. č. 1365, podsv. č. 2, 3.

71 Protestní rezoluce př́slušníků I. čs. partyzánské brigády Jana Žižky proti zavraždění mjr. Schramma, 8 Aug. 1948, Národní archiv, f. Úřad předsednictva vlády, běžná spisovna, sg. 1231/a, inv. č. 4138; 'Resoluce přijatá na zasedání ÚV SČP dne 4. prosince 1948', Partyzán, 10 Dec. 1948, 3. 


\section{Resistance, Provocation and Repression}

In the autumn of 1948 Slabík approached Rudolf Lenhard with instructions to expand the Světlana network into Wallachia. Lenhard had recently been in contact with Vávra-Stařík, to whom he confided his disillusionment with the new regime. Although he was himself a communist, he complained that the KSČ treated former partisans unfairly. His position as the leader of the Ploština branch of the SČP frequently brought him into contact with the grievances of local farmers and villagers. Workers' militias were sent into the countryside to enforce the fulfilment of agricultural quotas, which Lenhard described as a betrayal of the wartime 'efforts of the Wallachian people'. Communist functionaries were using the new homes built at Ploština to coerce the massacre's survivors into joining the KSČ. At a recent SČP meeting members had laughed openly at the official account of Vávra-Stařik's betrayal. The communist government was spreading lies to discredit the partisan movement and secure their own monopoly of power, declared one fighter: 'this can't go on any longer. You can't do anything without a [communist] star'. ${ }^{72}$

Lenhard and his associates drew on the partisan movement's social and organisational resources in their resistance activity. They received a mimeograph machine from Vávra-Stařík's former colleagues at Partkol and began producing leaflets. ${ }^{73}$ The people of Czechoslovakia, they wrote, had won the right to self-government through their suffering and heroism under Nazi occupation. But demoralised by war and politically and socially divided, the public had allowed 'a few usurpers and opportunists to force their will on our nation', as one leaflet stated. The state's persecution of the partisans demonstrated its betrayal of the nation, another read. The regime feared former resisters as representatives of legitimate power, while the people looked to them to unify the nation and lead it once again. Lenhard urged the public to form secret political groups, record the actions of unscrupulous functionaries and take independent action against 'national parasites' without fear of punishment. 'We stand with you and we are holding a protective hand above you. There are thousands of us.... We are everywhere and nowhere!' one leaflet proclaimed. ${ }^{74}$ Through partisan networks, Lenhard distributed his leaflets across Moravia. ${ }^{75}$

In January 1949 Lenhard sent a packet of leaflets to Alois Šimara in the borderland town of Hanušovice. Šimara shared them with his friends, including Ludvík Šmotek and Antonín Kratina, fellow partisans and natives of Wallachia. Like Lenhard, they had become dissatisfied with the new order, which they believed would not be long-lived. These leaflets confirmed their suspicions that their partisan comrades were preparing an uprising. While Lenhard instructed the men to remain where they were, circulate the leaflets and locate new recruits, they lacked the necessary social connections to establish an underground network in the borderlands. They resolved to return to Wallachia, where they would help to overthrow the communist government just as they had overthrown Nazi rule. ${ }^{76}$

Between April and May of 1949 Šimara and his men lived underground in the hills where they had fought as partisans. They drew on wartime connections, as well as their family and village ties, to find food, shelter and weapons, and to avoid arrest as they waited for the revolution they believed was

\footnotetext{
72 Úřední záznam 46/48, 2 Dec. 1948, ABS, f. Vyšetřovací spisy, inv. č. V-2670/Brno, Operativní materiál, podsv. 4, 21; Protokol sepsaný s Rudolfem Lenhardem, ABS, f. Vyšetřovací spisy, V-2670/Brno, 1-6; Protokol o výslechu - Josef Matúš, 25 Jan. 1966, 1, ABS, f. A8/1, inv. č. 1365, podsv. 2, 1-2.

73 Protokol sepsaný s Rudolfem Lenhardem, ABS, f. Vyšetřovací spisy, arch. č. V-2670/Brno, 21, 25-6, 32.

74 'Legionáři, partyzáni, zahraniční vojáci, osv. političtí vězni a ostatní odbojoví pracovníci', 'Narode český a slovenský!', 'Občané - Moravané!', ABS, f. Vyšetřovací spisy, arch. č. V-2670/Brno, Dokumenty z akce 'SVĚTLANA', 13, 15, 16.

75 Protokol sepsaný s Rudolfem Lenhardem, ABS, f. Vyšetřovací spisy, arch. č. V-2670/Brno, 38-39. These leaflets were found in Vsetín, Hodonín, Uherský Brod, Uherské Hradiště, and elsewhere. See Úřední záznam č. 75/49, 19 Jan. 1949; Ưřední záznam č. 28/49, 24 Feb. 1949; Letáky protistátního obsahu - hlášení, 25 Feb. 1949; Letáky protistátního obsahu - hlášení, 26 Feb. 1949 ABS, f. Vyšetřovací spisy, arch. č. V-2670/Brno, Operativní materiál, podsv. 4, 66, 69, 71 .

76 Protokol sepsaný s Ludvíkem Šmotkem, 4 June 1949, ABS, f. Vyšetřovací spisy, arch. č. V-2671/Brno, 12-13; Protokol sepsaný s Aloisem Šimarou, 22 June 1949, ABS, f. Vyšetřovací spisy, arch. č. V-2671/Brno, 2-6; Protokol sepsaný s Ludvíkem Šmotkem, 27 June 1949, ABS, f. Vyšetřovací spisy, arch. č. V-2671/Brno, 2-6, 8-11; Protokol sepsaný s Antonínem Kratinou, 6 July 1949, ABS, f. Vyšetřovací spisy, arch. č. V-2671/Brno, 2-4.
} 
imminent. They also adopted partisan tactics to establish their power and coerce the support of reticent or frightened locals. 'We have to shut the people's mouths', Šimara reportedly told one farmer, suggesting that he might execute villagers publicly to discourage denunciation. ${ }^{77}$ The police received an anonymous letter that spring: 'we inform you that [in the area of Ploština] there are armed bands that go around at night demanding food . . . they come and say they will burn or shoot anyone who betrays them. . . Please take quick action before anyone comes to harm. ${ }^{78}$

Šimara and his men arrived in Kratina's native village of Pozděchov shortly after their return to the region, where they met with a wartime comrade. Josef Prýšt was both a former partisan and an old communist, having joined the party in 1921, the year of its founding. After liberation he served as a communist member of the Pozděchov National Committee. ${ }^{79}$ He lost his KSČ membership after a dispute with the unpopular local party chairman, whom he identified as a former member of the now-banned Agrarian Party. Prýšt saw in Šimara's revolutionary ambitions the opportunity to avenge this personal grievance. Under interrogation Prýšt declared that he had indeed encouraged the attack that occurred later that night. ${ }^{80}$ When Šimara and his followers returned to Pozděchov a few days after the attack, Prýšt reportedly congratulated them on a job well done. ${ }^{81}$

The partisan movement and its place in village society made opposition in Wallachia particularly dangerous to the communist order. After the attack in Pozděchov police feared that Šimara and his men might spark the common resistance that Lenhard had called for in his leaflets. Two StB agents in partisan disguise sent on Šimara's trail in early May nervously noted that 'all members of the public who came into contact with our people greeted them heartily and offered them provisions, assuming they were partisans' ${ }^{82}$ But the partisan movement also provided agents with a template to ensnare both real and potential resisters. Šimara's group was captured after making contact with an StB agent posing as a member of French intelligence. The agent, Jaroslav Tureček, forbade the men from taking any further actions against local functionaries, instructing them to find recruits interested in participating in military training in France. They would return to Czechoslovakia as parachutists to liberate their country - or, Tureček also suggested, they might remain abroad for work. ${ }^{83}$ Among the new recruits was twenty-one year old Josef Fojtík, who had found himself wanted for questioning after an episode of unrest in his village in January 1949. Rather than risk arrest he fled to the forest. He eagerly accepted Šimara's offer to travel abroad, planning to join an uncle in the United States. Another very young recruit, Antonín Martinka, had been in hiding after publicly insulting the prime minister. Josef Tomeček, whom Tureček initially used to contact Šimara, saw in the agent's promises the opportunity to escape a difficult family life. ${ }^{84}$ Šimara arranged to have his men picked up on the night of 30 May 1949. They were driven to a forest outside the town of Jihlava, lured outside and arrested. $^{85}$

\footnotetext{
77 Protokol sepsaný s Jiřím Vařákem, 22 July 1949, ABS, f. Vyšetřovací spisy, arch. č. V-2671/Brno, 3.

78 Anonymous letter, 9 May 1949, 43, ABS, f. Vyšetřovací spisy, arch. č. V-2670/Brno, Operativní materiál, podsv. 1, 43.

79 'Zápis o výpovědi s podežrelým Pryštěm Josefem', 14 Sept. 1949, ABS, f. Vyšetřovací spisy, V-2671/Brno, 1; Pamětní kniha obce Pozděchova od r. 1924, SOkA Vsetín, f. AO Pozděchov, inv. č. 11, 62.

80 Zápis o výpovědi s podezřelým Pryštěm Josefem, 14 Sept. 1949, ABS, f. Vyšetřovací spisy, V-2671/Brno, 2, 4.

81 Protokol sepsaný s Aloisem Šimarou, 22 June 1949, ABS, f. Vyšetřovací spisy, V-2671/Brno, 12.

82 Světlana Jarmila a Makyta - likvidace, 2 May 1949, ABS, f. Vyšetřovací spisy, V-2670/Brno, Operativní materiál, podsv. 1, 51-2.

83 Protokol sepsaný s Aloisem Šimarou, 22 June 1949, ABS, f. Vyšetřovací spisy, arch. č. V-2671/Brno, 25-6; Zápis o výpovědi - Jaroslav Tureček, 18 Dec. 1955, ABS, f. A8/1, inv. č. 1365, 3, 6.

84 Protokol sepsaný s Josefem Fojtíkem, 27 June 1949, ABS, f. Vyšetřovací spisy, arch. č. V-2671/Brno, 2, 10; Protokol sepsaný s Antonínem Martinkou, 11 July 1949, ABS, f. Vyšetřovací spisy, arch. č. V-2671/Brno, 2; Protokol sepsaný s Josefem Tomečkem, 12 July 1949, ABS, f. Vyšetřovací spisy, arch. č. V-2671/Brno, 2-5; Zpráva o prošetření připadu Aloisie Doležalové, 27 Feb. 1956, ABS, f. A8/1, inv. č. 1365, 6.

85 Protokol sepsaný s Aloisem Šimarou, 22 June 1949, ABS, f. Vyšetřovací spisy, inv. č. V-2671/Brno, 34-6; Zpráva o prověřování stížností osob, odsouzených pro činnost v protistátní organizaci 'SVĚTLANA', ABS, f. A8/1, inv. č. 1365, podsv. 1, 9-10.
} 
Through Světlana the StB created a mechanism for turning both actual resistance and simple local grievance into conspiracy. Tureček was not the only infiltrator in the network. An informant printed some of Lenhard's leaflets in his own home while keeping the police apprised of all the group's activities. ${ }^{86}$ To its members Světlana represented a renewal of their patriotic wartime resistance, while to the police it confirmed the danger posed by their ideological and political enemies. For the public Světlana brought official propaganda to life. The trial of Alois Šimara et al. was held in July 1950 in a Vsetín theatre packed with local workers. Loudspeakers on the town's streets broadcast the proceedings. 'Our people will settle scores with spies and wreckers!' announced a headline in Naše pravda. Men like Lenhard and Šimara presented themselves as freedom fighters and communists, the press explained, but conspired with the nation's enemies to usurp power for themselves. Only through their detection and punishment could the republic and its people be secure. 'Now that the Wallachian mountains are cleared of such elements, the Wallachian people, whose sacrifices under fascism were so great, can live in peace', one article concluded. ${ }^{87}$

Josef Vávra-Stař́k was kidnapped in Vienna by StB agents and imprisoned in Prague, where he came to play a supporting role in the fantastical stories of conspiracy and treason unspooling at the centre of Czechoslovak politics. ${ }^{8}$ In May 1950 he appeared as a witness in the show trial of Milada Horáková, a former member of the National Assembly cast as the leader of a fifth column, working with Western agents and reactionary émigrés against the Czechoslovak state. ${ }^{89}$ Although Vávra-Stařík could share no information about Horáková or any of her twelve co-defendants, his testimony served to discredit the communists' exiled opponents. ${ }^{90}$ In Paris, he claimed, he had witnessed Czechoslovakia's former political elite cooperating with fascists and imperialists to orchestrate a new Munich and enable their own return to power. ${ }^{91}$ Vávra-Stařík's name also appeared in the infamous 1952 trial of Rudolf Slánský, which 'unmasked' the KSČ General Secretary as an enemy of the Czechoslovak people and their communist leaders. ${ }^{92}$ Slánskýs interrogators reinterpreted his entire political life, including his place in the partisan movement, to fit a narrative of subversion. ${ }^{93}$ By emphasising partisan achievements and advocating that former fighters take leading positions in public life, Slánský had cleverly undermined the 'leading role' of the KSČ. His connections to 'false partisans' like Vávra-Stař́k provided further evidence of his treason. ${ }^{94}$

According to the Vysoké Pole village chronicle, in the year 1949 'various groups of people began to form, which attempted to conduct sabotage against the state with the help of foreign agents and various spies'. The chronicler adopted official rhetoric but hinted at the suffering that state repression had brought to his village. Ten men from Vysoké Pole and neighbouring communities had been detained,

86 Úřední záznam 89/49, 15 Feb. 1949, ABS, f. Vyšetřovací spisy, V-2670/Brno, Operativní materiál, podsv. 4, 64; Protokol o výslechu - Václav Kocourek, 13 Jan. 1966, ABS, f. A8/1, inv. č. 1365, podsv. 3, 2; Protokol o výslechu - Rudolf Bezděk, 13 Jan. 1966, ABS, f. A8/1, inv. č. 1365, podsv. 3, 1-2.

87 'Odhalujeme tvář neprátel pracujících', Tep svobodné práce, 28 Apr. 1950, 7; 'Republiku si rozvracet nedame!', Naše pravda, 6 May 1950, 10; 'Velezrádci Světlany-Jeseník před státním soudem na Vsetíně’, Naše pravda, 22 July $1950,2$.

88 Zpráva o prošetření případu SVĚTLANA na základě Generální prokuratury v Praze ze dne 8.6.1965, 27 Apr. 1966, ABS, f. A8/1, inv. č. 1365 , podsv. 4, 6-7.

89 See Karel Kaplan, Největši politický proces M. Horáková a spol. (Brno, Doplněk, 2005); Melissa Feinberg, Elusive Equality, 211-22; Pavlína Formánková and Petr Koura, Žádáme trest smrti! Propagandistická kampaň provázející proces s Miladou Horakovou a spol. (Prague: Ústav pro studium totalitních režimu, 2008), 25-121.

90 Zápis o poradě ve věci Direktoria ze dne 3.5.1950, konané na ministerstvu vnitra, in Formánková and Koura, Žádáme trest smrti!, 193-5.

91 'Dnes bude vynesen rozsudek nad vedením záškodnického spiknutí proti republice', Rudé právo, 8 June 1950, 5.

92 See Karel Kaplan, Report on the Murder of the General Secretary (Columbus: Ohio State University Press, 1990); Kevin McDermott, 'A "Polyphony of Voices"? Czech Popular Opinion and the Slánský Affair', Slavic Review 67, 4 (Winter 2008); Melissa Feinberg, 'Fantastic Truths, Compelling Lies: Radio Free Europe and the Response to the Slánský Trial in Czechoslovakia', Contemporary European History, 22, 1 (2013).

93 For the reinterpretation of biographies under interrogation, see Melissa Feinberg, Curtain of Lies: The Battle over Truth in Stalinist Eastern Europe (New York: Oxford University Press, 2017), 19-22.

94 Protokol o výpovědi, 26 Aug. 1952, ABS, arch. č. MNB-1, f. Slánský Rudolf, část 15, 530-40; Proces s vedením protistátního spikleneckého centra v čele s Rudolfem Slánským (Prague: Ministerstvo vnitra, 1953), 85. 
many of them small farmers whose absence put a significant burden on their wives and children. Throughout the village, the chronicler concluded, citizens 'were shaking with fear and worry that they too would be arrested'. ${ }^{95}$ The Světlana case produced hundreds of arrests, multiple trials and several executions, including those of Rudolf Lenhard and Alois Šimara. Šmotek, Kratina, Prýšt, Fojtík, Martinka and Tomeček received long prison terms, as did the many other Wallachian villagers and farmers who assisted Šimara and his men during their time in hiding. ${ }^{96}$ In 1953 Josef Vávra-Stařík was brought to the gallows. When asked for his final words, after mentioning his wife, he declared: 'I die for the partisans' glory'. 97

\section{Conclusion}

The partisan movement was among the KSČ's most reliable and radical allies prior to 1948. Partisans served as symbols of social revolution and provided party activists with organisational support. After the establishment of communist dictatorship, partisan institutions were reinvented as instruments of official power. Former partisans campaigned for collectivisation and recruited volunteers for work brigades in the coal mines. ${ }^{98}$ Stories of partisan struggle and local sacrifice tied Moravian Wallachia to the official narrative of Czechoslovak history. Ploština became a site for official rallies and Pioneer ceremonies. ${ }^{99}$ And yet, within a year of the KSČ's seizure of power, former partisans in this remote corner of the republic were calling for resistance to the new regime.

This case highlights the contested nature of people's democracy in post-war Czechoslovakia. The replacement of local, district and regional governments after 1945 by National Committees effected a revolution in local administration, enabled the emergence of new elites and confirmed the popular basis of power. Former partisans saw themselves as the guardians of the new order, leading them to support communist demands for thorough purges of public life and the state bureaucracy. Communist leaders legitimised their seizure of power through the rhetoric and practices of people's democracy, successfully mobilising the public to extend and entrench one-party rule. But the KSČ's conception of people's democracy came directly into conflict with that held by many former partisans, for whom no political party could legitimately claim a 'leading role' in Czechoslovak society. This right, they believed, belonged exclusively to those who had liberated that society from fascist domination. While the revolution of 1945 indeed paved the way for the coup of 1948, as many have argued, the ideals of people's democracy also inspired resistance to the consolidating communist regime.

Světlana also illustrates the broader context of Stalinist repression in Czechoslovakia. StB agents drew on partisan tactics and practices to construct cases and trials that presented partisans as enemies of the people. Stalinist show trials employed the political language used by former partisans against their external political opponents and internal rivals, describing a world of subversion, hidden enemies and secret plots. The Světlana trials both echoed narratives appearing in the Horáková trial and anticipated those put forth in the trial of Slánský. Moreover, local campaigns of repression during the communist regime's early years provided necessary experience for the ambitious young cadres who carried out the Stalinisation of the Czechoslovak police. Agents involved in the investigation and interrogation of Světlana's members, notably Ludvík Hlavačka and Milan Moučka, went on to successful careers in the security services. ${ }^{100}$

\footnotetext{
95 Pamětní kniha obce Vys. Pole, SOkA Zlín, f. ObÚ Vysoké Pole, inv. č. 2, 109-10.

96 Sentence against Rudolf Lenhard et al., 29 Apr. 1950, ABS, f. Vyšetřovací spisy, inv. č. V-2670/Brno, 4-7; Sentence against Alois Šimara et al., 15 July 1950, ABS, f. Vyšetřovací spisy, inv. č. V-2671/Brno, 5-7; Homola et al., Př́ipad Světlana, 22.

97 Opis protokolu o výkonu trestu smrti na odsouzeném Josefa Vávru-Stař́íkovi dne 26. srpna 1953, 8 Oct. 1965, ABS, f. A8/ 1, inv. č. 1365, podsv. 4, 253.

98 Letter to SBS local and district branches from Zlín regional secretariat, 20 Apr. 1950; letter to SBS local and district branches from Zlín regional secretariat, 8 June 1950, SOkA Zlín, f. SPB-OV Gottwaldov, balík 17.

99 Tomáš Chmela, Ploština: prríbeh psaný ohněm (Nymburk: Vega-L, 2010), 25-7.

100 Pucci, 'A Revolution in a Revolution', 11-5; Homola et al., Případ Světlana, 54, 67.
} 
Finally, Světlana presents a case study of the local dynamics that shaped both state power and popular politics in Czechoslovakia. Former partisans in Moravian Wallachia articulated a distinct vision of a just post-war order rooted in their regional identities and local experiences. By placing themselves within a local tradition of popular resistance, they laid claim to material and symbolic benefits for themselves and their communities. The consolidating communist dictatorship's disregard for Wallachian interests demonstrated to former partisans the illegitimacy of its power. Wartime networks and strategies of resistance embedded in the region's social and physical environment were repurposed against the new regime, and in turn mobilised against rebellious former partisans by agents of state repression. Both the regime and its opponents relied on local connections and knowledge.

The cataclysm of the Second World War shaped the hopes and expectations of both national leaders and ordinary citizens across the European continent. However, both local experiences of occupation, persecution and resistance, as well as local dreams of post-war justice, could differ dramatically from those presented in the halls of power. Světlana suggests the diversity of popular politics in postwar Europe hidden behind national narratives and ideological abstractions.

Acknowledgments. I would like to thank Chad Bryant, Donald J. Raleigh, Karen Auerbach and W. Fitzhugh Brundage, as well as Till Knobloch, Oskar Czendze and the participants in the UNC-Chapel Hill European History Workshop for their assistance in the development of this article, and Hana Píchová for her help with translation. I also thank Celia Donert and the editors of Contemporary European History, as well as the three anonymous reviewers, for their insight and suggestions.

Cite this article: Markham M (2021). Světlana: Partisans and Power in Post-War Czechoslovakia. Contemporary European History 30, 16-31. https://doi.org/10.1017/S0960777320000508 